\title{
NALAR KEBERAGAMAAN MASYARAKAT BANJAR: DARI MISTIS-REALIS HINGGA TRADISIONALIS-KRITIS
}

\author{
Wardatun Nadhiroh \\ UIN Antasari Banjarmasin \\ wnadhiroh@uin-antasari.ac.id
}

Diterima 20 Juni 2019| Direview 25 Desember 2019 | Diterbitkan 28 Desember 2019

\begin{abstract}
The Banjar community, which consists of the Banjar ethnic group, is referred to as a tribe that overlaps between ethnic and religious identities. When mentioned with the word "Banjar", it will be imagined the word "Islam" accompanies it. The inherent stamp of "Banjar Islam" shows a certain religious dimension in it which is certainly different from other Muslims. This article is presented to illustrate the typology of religious reasoning of Banjar people who are associated with the label of Banjar Islam in front of them. It should be noted that far from the arrival of Islam, Banjar people also developed the belief in animism-dynamism followed by Hinduism and Buddhism. It was thanks to the role of the Banjar Sultanate that the Banjar community became the Banjar Islam. In the end, a shift in reason also occurred in the religious constructs of the Banjar community in line with social changes. This paper is a literature study that relies on descriptive methods in its presentation and psycho-socio-historical approach as the knife of analysis. This article explains that there are at least 4 types of reasoning that developed in Banjar since the era of animism and dynamism until after the entry of religious movements in the 20th century, namely mystical-realist, mystical-idealist, literalistnormative, and traditionalist-critical. The development of the religious reasoning of the Banjar community did not occur linearly, but rather overlapping.
\end{abstract}

Keywords: Religious reasoning, Banjar people, overlapping.

\begin{abstract}
Abstrak
Masyarakat Banjar yang terdiri dari etnis Banjar disebut sebagai suku yang bertumpang-tindih antara identitas kesukuan dan identitas keagamaannya. Ketika disebutkan dengan kata Banjar, maka akan terbayang kata Islam menyertainya. Cap "Islam Banjar" yang melekat menunjukkan adanya suatu dimensi keberagamaan tertentu di dalamnya yang tentunya berbeda dengan Islam-Islam lainya. Artikel ini dihadirkan untuk menggambarkan tipologi nalar beragama masyarakat Banjar dikaitkan dengan adanya label Islam
\end{abstract}


Banjar di depannya. Perlu diketahui bahwa jauh kedatangan Islam, di Banjar pun juga berkembang kepercayaan animisme-dinamisme yang disusul agama Hindu dan Buddha. Berkat peran kesultanan Banjarlah masyarakat Banjar menjadi Islam Banjar. Pada akbirnya, pergeseran nalar pun juga terjadi dalam konstruk keberagamaan masyarakat Banjar seiring perubahan sosial kemasyarakatan. Tulisan ini adalah kajian kepustakaan yang mengandalkan metode deskriptif dalam pemaparannya dan pendekatan psiko-sosio-historis sebagai pisau analisisnya. Artikel ini menjelaskan babwa setidaknya ada 4 tipologi nalar yang berkembang sejak animisme dan dinamisme hingga pasca masuknya gerakan keagamaan di abad 20, yaitu mistis-realis, mistis idealis, literalis normatif, dan tradisionalis-kritis. Perkembangan nalar kekeberagamaan masyarakat Banjar tidak terjadi evolusi linier, namun lebih bersifat overlapping.

Kata kunci: Nalar beragama, masyarakat Banjar, overlapping.

\section{Pendahuluan}

Selama ini orang banyak yang salah memahami antara arti dari agama dan keberagamaan. Seseorang dituduh teroris, namun yang disalahkan adalah agamanya, padahal sebenarnya nalar keberagamaannya lah yang salah. Agama adalah pedoman atau ajaran dari Tuhan untuk pemeluknya. ${ }^{1}$ Sementara keberagamaan adalah hasil manifestasi pemahaman pemeluk agama terhadap agama tersebut yang terwujud dalam perilaku beragama. Seorang Muslim melakukan kejahatan bukan agama Islamnya yang mengajarkan demikian tapi cara dia bernalar dalam memahami agama itu yang harus dipertanyakan kembali kebenarannya. Agama hadir dalam beragam bentuk keberagamaan tergantung pada pengikut dan latar belakangnya sebagai manusia yang menyejarah.

Masyarakat Banjar yang identitas keagamaannya tumpang tindih dengan identitas kesukuannya ${ }^{2}$ sehingga sering disebut dengan Islam Banjar tentunya memiliki ciri khas keislaman dan keberagamaannya sendiri. Ciri khas perilaku

\footnotetext{
${ }^{1}$ Kiki Muhamad Hakiki, "Politik Identitas Agama Lokal (Studi Kasus Aliran Kebatinan)," Analisis: Jurnal Studi Keislaman 11, no. 1 (2011): 160-61, https://doi.org/10.24042/ajsk.v11i1.617.

2 Ahmad Gaus A. F, Sang Pelintas Batas: Biografi Djohan Effendi, ed. Hairus Salim (Jakarta: Penerbit Buku Kompas, 2009), xi-xxii; Supriansyah Supriansyah, "Agresi Kultur Digital dan Konsumerisme ada Identitas Urang Banjar di Era Pascamodern," Al-Banjari: Jurnal Ilmiah IlmuIlmu Keislaman 18, no. 1 (2019): 106, https://doi.org/10.18592/al-banjari.v18i1.2544.
} 
keagamaan pra-Islam yang masih melekat kuat dalam budayanya ${ }^{3}$ hingga sosok ulama atau tuan guru yang menjadi sentral beragama masyarakat Banjar ${ }^{4}$ membuat wajah Islam Banjar masih terkesan kaku. Langkah-langkah kritis untuk mendobrak kekakuan tersebut tidak begitu memiliki implikasi signifikan dalam memodifikasi wajah Islam Banjar. Penyebab utamanya adalah tidak meratanya kehadiran tokoh yang mampu 'berdiri' dan mewacanakan kekritisan tersebut terhadap masyarakat Banjar.

Tulisan ini bermaksud mengeksplor tipologi keberagamaan masyarakat Banjar untuk menemukan nalar yang berkembang dan mendasari perilaku beragama di Banjar. Jenis penelitian ini adalah kepustakaan dengan mengandalkan metode deskripsi untuk pemaparannya dan pendekatan sosiohistoris sebagai alat analisisnya. Diharapkan tulisan ini mampu memperkaya wawasan Islam yang berkembang di Nusantara, khususnya memperkenalkan nalar keberagamaan Islam yang berkembang di Kalimantan Selatan.

\section{Agama dan Keberagamaan; Suatu Distingsi}

Agama dan keberagamaan adalah dua kata yang mengandung arti yang berbeda. Secara morfologis, masing-masing ungkapan tentu punya artinya sendiri. Dalam kaidah kebahasaan, perubahan bentuk kata dasar agama menjadi keberagamaan menyatakan bahwa keduanya harus dipakai dan diberi makna yang berbeda. Agama merupakan kata benda dan keberagamaan adalah kata sifat atau keadaan. ${ }^{5}$

Munawir Haris, mengutip pernyataan Mukti Ali tentang definisi agama bahwa tidak ada kata yang paling sulit didefinisikan kecuali kata agama dikarenakan tiga alasan. Pertama, pengalaman agama bersifat subjektif dan sangat individualis. Kedua, pembahasan agama selalu melibatkan emosi yang kuat. Ketiga, konsepsi seseorang tentang agama selalu dipengaruhi oleh tujuan

\footnotetext{
${ }^{3}$ Muhammad Iqbal Noor, "Nalar Keislaman Urang Banjar," Al-Banjari: Jurnal Ilmiah Ilmu-Ilmu Keislaman 10, no. 2 (2011), https://doi.org/10.18592/al-banjari.v10i2.935.

4 Ahdi Makmur, "Peranan Ulama Dalam Membina Masyarakat Banjar Di Kalimantan Selatan," MIQOT: Jurnal Ilmu-Ilmu Keislaman 36, no. 1 (2012), https://doi.org/10.30821/miqot.v36i1.114; Wardatun Nadhiroh, "Religious and Gender Issues in the Tradition of Basurung and the Polygamy of Banjar Tuan Guru in South Kalimantan," Al-Albab 6, no. 2 (2017): 263-80, https://doi.org/10.24260/alalbab.v6i2.674.

${ }^{5}$ Munawir Haris, “Agama Dan Keberagamaan: Sebuah Klarifikasi Untuk Empati," Al'Adalah 16, no. 2 (2016): 209, http://ejournal.iain-jember.ac.id/index.php/aladalah/article/view/160.
} 
orang itu memberikan arti terhadap agama itu." Adapun dalam Seven Theories of Religion disebutkan, agama adalah the faith in Spritual Beings (kepercayaan terhadap wujud spiritual). ${ }^{7}$ Sedangkan, Permata dalam Metodologi Studi Agama menjelaskan bahwa agama ialah sikap yang serius dan sosial dari individuindividu atau komunitas-komunitas kepada satu atau lebih kekuatan yang mereka anggap memiliki kekuasaan tertinggi terhadap kepentingan dan nasib mereka. ${ }^{8}$

Selanjutnya, Harun Nasution sebagaimana dikutip oleh Haris juga memberikan sejumlah definisi agama, yaitu: (1) Pengakuan terhadap adanya hubungan manusia dengan kekuatan gaib yang harus dipatuhi; (2) Mengikatkan diri pada suatu bentuk hidup yang mengandung pengakuan pada suatu sumber yang berada di luar diri manusia dan yang mempengaruhi perbuatan-perbuatan manusia; (3) Kepercayaan pada suatu kekuatan gaib yang menim-bulkan cara hidup tertentu; (4) Pengakuan terhadap adanya kewajiban-kewajiban yang diyakini bersumber pada suatu kekuatan gaib; (5) Pemujaan terhadap kekuatan gaib yang timbul dari perasaan lemah dan perasaan takut terhadap kekuatan misterius yang terdapat dalam alam sekitar manusia. ${ }^{9}$

Dari beberapa definisi di atas, paling tidak dapat disimpulkan bahwa agama merupakan sesuatu yang melekat pada diri manusia yang beragama. ${ }^{10}$ Agama tidak dipandang sebagai kata benda, melainkan sebagai kata sifat atau bahkan kata kerja karena semua definisi ini menunjuk pada keadaan atau aktivitas yang melekat pada diri manusia. Oleh karena itu, semua definisi tersebut lebih tepat digunakan untuk menjelaskan arti keberagamaan, bukan arti agama. $^{11}$

Faridah mengutip penjelasan Rangkuti, bahwa kata agama berasal dari bahasa Sanskerta, a-gama (dengan a panjang). $A$ berarti cara (the way), dan gama berarti to go, yaitu berjalan atau pergi. Bertolak dari pengertian itu, ditegaskan lebih jauh bahwa agama berarti cara-cara berjalan untuk sampai kepada

\footnotetext{
${ }^{6}$ Haris, 210.

${ }^{7}$ Daniel L. Pals, Seven Theories of Religion (Oxford University Press, 1996).

${ }^{8}$ Ahmad Norma Permata, Metodologi Studi Agama (Yogyakarta: Pustaka Pelajar, 2000).

${ }^{9}$ Haris, “Agama Dan Keberagamaan,” 210-11.

${ }^{10}$ Siti Faridah, "Kebebasan Beragama dan Ranah Toleransinya," Lex Scientia Law Review 2, no. 2 (2018): 204, https://doi.org/10.15294/lesrev.v2i2.27585.

${ }^{11}$ Haris, “Agama Dan Keberagamaan,” 211.
} 
keridhaan Tuhan. ${ }^{12}$ Dari sini, dapat dipahami bahwa agama merupakan jalan hidup (the way to go) yang mesti ditempuh atau pedoman yang harus diikuti. Pengertian ini sejalan dengan makna agama dalam Bahasa Arab syari'ah, secara harfiah berarti jalan menuju sumber mata air, ${ }^{13}$ sementara air adalah sumber kehidupan manusia. Jadi syariah berarti jalan menuju sumber kehidupan atau jalan hidup (way of life) ${ }^{14}$ Berdasar uraian di atas, dapat dipahami bahwa agama merupakan suatu wujud yang berdiri sendiri dan berada di luar diri manusia.

Secara definitif, agama adalah ajaran, petunjuk, perintah, larangan, hukum, dan peraturan, yang diyakini oleh penganutnya berasal dari dzat gaib Yang Maha Kuasa, yang dipakai manusia sebagai pedoman tindakan dan tingkah laku dalam menjalani hidup sehari-hari. Dengan kata lain, inti dari suatu agama ialah ajaran yang dipakai manusia sebagai pedoman hidup. ${ }^{15}$

Adapun keberagamaan adalah pelaksanaan agama itu sendiri yang sangat mungkin menghasilkan perbedaan antara satu dan yang lainnya disebabkan perbedaan tingkat pengetahuan dan keyakinan, atau bisa jadi dikarenakan perbedaan background geografis dan sosio-kultural pelaku ajaran agama itu sendiri. Walaupun secara teoritis keberagaman harus merepresentasikan agama, namun tidaklah benar menilai suatu agama dengan menjadikan sebagian perilaku umat beragamanya (keberagamaan) sebagai satusatunya tolak ukur. Agama Islam bukanlah secara otomatis sama dengan sikap dan amalan orang yang mengaku sebagai penganut Islam. Belum tentu, seorang yang mengaku beragama Islam sudah mencerminkan agama Islam yang sesungguhnya. Begitu pula, agama Kristen boleh jadi tidak seperti yang dipraktikkan oleh mereka yang mengaku sebagai penganut Kristen. Sikap dan amalan setiap penganut agama adalah wujud keberagamaan, yang menggambarkan sifat dan tingkat keyakinan, pemahaman dan kesetiaan mereka terhadap agamanya masing-masing.

Menurut Glock dan Stark, sebagaimana dikutip Roni Ismail, keberagamaan muncul dalam lima dimensi, yakni dimensi ideologis, intelektual,

\footnotetext{
${ }^{12}$ Faridah, "Kebebasan Beragama dan Ranah Toleransinya," 204.

${ }^{13}$ Abu al-Qasim al-Husayn ibn Muhammad Raghib Al-Asfahani, Al-Mufradat fi Gharib al-Qur'an (Beirut: Turath For Solutions, 2013), 258; Haris, “Agama Dan Keberagamaan,” 213.

14 Haris, "Agama Dan Keberagamaan," 213; Faridah, "Kebebasan Beragama Dan Ranah Toleransinya," 204.

${ }^{15}$ Faridah, "Kebebasan Beragama dan Ranah Toleransinya," 204.
} 
eksperiensial, ritualistik, dan konsekuensial. ${ }^{16}$ Dimensi ideologis dan intelektual merepresentasikan aspek kognitif keberagamaan, dimensi eskperiensial mewakili aspek afeksi, sementara dimensi ritualistik dan konsekuensial melambangkan aspek behavior dari keberagamaan. ${ }^{17}$ Kelima dimensi di atas dapat dibedakan melalui aneka ragam dan unsur yang meliputinya, yakni bentuk keyakinan, praktek, pengalaman, pengetahuan dan konsekuensi yang muncul.

Pertama, dimensi ideologis meliputi seperangkat kepercayaan yang memberikan premis eksistensial untuk menjelaskan Tuhan, alam, manusia dan hubungan antara mereka. ${ }^{18}$ Dimensi ini merupakan bagian dari keberagamaan yang berkaitan dengan apa yang harus dipercayai dan menjadi system keyakinan dimana menjadi isu paling dasar yang bisa membedakan agama satu dengan yang lainnya. Dalam Islam, keyakinan ini tertuang dalam dimensi akidah.

Kedua, dimensi intelektual yang mengacu pada pengetahuan tentang ajaran-ajaran agama yang harus diketahui seorang pemeluknya. Dalam Islam misalnya, pengetahuan yang dimaksud bisa tentang al-Qur'an dengan cara baca, isi, dan kandungan maknanya, hadis, berbagai praktek ritual dan muamalah, konsep keimanan, dan lain-lain. Dimensi ini pada dasarnya dapat diarahkan untuk mengetahui seberapa jauh tingkat pemahaman agama para pengikut agama atau tingkat ketertarikan mereka dalam mempelajari agamanya. ${ }^{19}$ Seorang pemeluk agama harus melalui dimensi ini sebagai syarat penerimaannya. Namun bukan berarti dengan pengetahuan yang sedikit menjadikan keberagamaannya menjadi tidak baik. Seseorang dapat memiliki keyakinan yang kuat pada agama dengan dasar pengetahuan yang sedikit.

Ketiga, dimensi eksperiensial merupakan bagian keberagamaan yang bersifat afektif, yaitu keterlibatan emosional dan sentimental pada pelaksanaan ajaran agama yang merupakan perasaan keagamaan (religious feeling) ${ }^{20}$ dapat

${ }^{16}$ Roni Ismail, "Keberagamaan Koruptor Menurut Psikologi (Tinjauan Orientasi Keagamaan Dan Psikografi Agama)," ESENSLA: Jurnal Ilmu-Ilmu Ushuluddin 13, no. 2 (2012): 295-96, https://doi.org/10.14421/esensia.v13i2.743.

17 Murniati, "Pengembangan Keberagamaan Siswa dalam Aspek Akhlak melalui Metode Keteladanan di SD Alam Bandung," Atthulab: Islamic Religion Teaching and Learning Journal 4, no. 1 (2019): 57, https://doi.org/10.15575/ath.v4i1.2948.

18 Murniati, 57.

${ }^{19}$ Murniati, 57-58.

20 Murniati, "Pengembangan Keberagamaan Siswa dalam Aspek Akhlak melalui Metode Keteladanan di SD Alam Bandung." 
bergerak pada beberapa tingkat, yakni 1) konfirmatif, merasakan kehadiran Tuhan menjawab kehendak atau keluhannya, 2) eskatik, merasakan hubungan yang akrab dan penuh cinta dengan Tuhan, dan 3) partisipatif, merasa menjadi kawan setia atau kekasih Tuhan. Menurut Zakiyah Darajat, Psikologi Agama menyebutnya sebagai pengalaman keagamaan (religious experience), yaitu unsur perasaan dalam kesadaran agama yang membawa pada suatu keyakinan. ${ }^{21}$ Pengalaman keagamaan ini bisa terjadi dari yang paling sederhana seperti merasakan kekhusyukan dan ketenangan ketika shalat, kebahagiaan menjalani puasa Ramadhan, hingga pengalaman yang lebih kompleks seperti pengalaman ma'rifah yang dialami para sufi. Dalam Islam, pola keber-agamaan yang demikian dapat dibedakan dari tingkat yang paling rendah adalah syari'ah, kemudian thariqah, dan derajat tertinggi adalah haqiqah.

Keempat, dimensi ritualistik merupakan bagian dari keberagamaan yang berkaitan dengan perilaku atau sering disebut ritual keagamaan, seperti pemujaan dan ritus-ritus lainnya yang diikuti dengan ketaatan untuk menunjukkan komitmennya terhadap agama yang dianut. ${ }^{22}$ Dimensi ini sejajar dengan ibadah dalam agama Islam.

Kelima, dimensi konsekuensional meliputi segala implikasi sosial dari pelak-sanaan ajaran agama. Dimensi ini mengacu pada identifikasi akibat dari keyakinan, praktek, pengalaman, dan pengetahuan seseorang dari hari ke hari walaupun pada dasarnya, agama banyak menggariskan bagaimana pemeluknya seharusnya berpikir dan bertindak dalam kehidupan sehari-hari. ${ }^{23}$ Dalam Islam, dimensi ini hadir dalam perilaku yang berkaitan dengan hubungan pada sesama manusia (bablun min al-nas). Ajaran Islam banyak mendorong umatnya untuk menghormati tetangga, memuliakan tamu, toleran, berbuat adil, berbuat baik pada fakir miskin dan anak yatim, dan sebagainya.

\section{Bernalar dalam Beragama}

Nalar merupakan suatu hal yang tak terpisahkan dari diri manusia. Dalam Kamus Besar Bahasa Indonesia, nalar diartikan sebagai 1) selalu, 2) pertimbangan (baik atau buruk), dan 3) aktivitas yang memungkinkan sese-

\footnotetext{
${ }^{21}$ Zakiah Daradjat, Imu Jiwa Agama (Jakarta: PT. Bulan Bintang, 1996).

22 Murniati, "Pengembangan Keberagamaan Siswa dalam Aspek Akhlak melalui Metode Keteladanan di SD Alam Bandung," 58.

${ }^{23}$ Murniati, 58.
} 
orang berpikir logis; jangkauan pikir; kekuatan pikir. ${ }^{24}$ Namun nalar berbeda dengan logika. M. Atar Semi menyatakan logika lebih kompleks daripada nalar karena logika dibuat dengan penjelasan ilmiah yang dinyatakan dalam bahasa. Sedangkan nalar bertolak dari pengamatan indera atau yang biasa disebut insting..$^{25}$

Kajian tentang nalar dewasa ini menjadi tren dalam studi Islam. Sebut saja Arkoun dengan Kritik Nalar Islamnya mencoba mengembalikan produkproduk pemikiran kepada kesejarahannya dan melakukan pembongkaran wacana. ${ }^{26}$ Muhammad Abid al-Jabiri dengan Kritik Nalar Arabnya mencoba mengupas wacana pemikiran Islam yang telah ada melalui pendekatan epistemologis dan ideologis yang melahirkan nalar bayani, nalar burbani, dan nalar irfani. ${ }^{27}$ Sementara Ali Harb dengan Kritik Teksnya mengkritik para kritikus sebelumnya, terutama dua intelektual yang telah disebutkan sebagai 'pemuja nalar'. Menurutnya, rekontruksi nalar yang dilakukan menjadi omong kosong tanpa melakukan dekonstruksi terhadap 'teks' yang telah menelurkan nalar-nalar tersebut. ${ }^{28}$

Terlepas dari perdebatan tersebut, yang dimaksud nalar di sini adalah nalar subyektif seseorang atau sekelompok golongan. Dalam bukunya al-Jabiri istilah nalar dapat dibagi menjadi dua, yaitu nalar obyektif dan nalar subyektif. ${ }^{29}$ Nalar obyektif adalah nalar yang digunakan setiap orang untuk berpikir terlepas dari latar belakang eksistensialnya. Dengan nalar ini, setiap orang dapat memahami bahwa air yang dipanaskan hingga $100^{\circ} \mathrm{C}$ akan mendidih, tidak peduli dia berasal dari bangsa apa, tinggal di mana, karena semua itu tidak ditentukan oleh latar belakang eksistensialnya. Sedangkan nalar subyektif adalah nalar yang terikat dan terbentuk oleh latar belakang esksistensial seorang anak

\footnotetext{
24 Pusat Bahasa (Indonesia), Kamus Besar Bahasa Indonesia (Jakarta: Gramedia Pustaka Utama, 2008), 994.

${ }^{25}$ M. Atar Semi, Anatomi sastra (Bandung: Angkasa Raya, 1993).

${ }^{26}$ Muhammad Arkoun, Tarikhiyyah Al-Fiker al-Arabiy al-Islamiy (Libanon: Markaz al-Inma' alKoumi, 1986).

${ }^{27}$ M. Abid Al-Jabiri, Takwin Al-Aql al-Arabiy (Beirut: Markaz Dirasat al-Wihdah al-Arabiyyah, 1989); M. Abid Al-Jabiri, Bunyah Al-Aql al-Arabiy (Beirut: Markaz Dirasat al-Wihdah alArabiyyah, 1990).

${ }^{28}$ Ali Harb, Kritik Nalar Al-Qur'an (Yogyakarta: LKiS, 2003).

${ }^{29}$ Al-Jabiri, Takwin Al-Aql al-Arabiy.
} 
manusia yang menyejarah. Nalar inilah yang menjadi perhatian para tokoh di atas. $^{30}$

Dalam perilaku beragama, nalar berperan dalam memahami dan mewujudkan ajaran-ajaran agama, terutama ketika ia harus bersentuhan dengan kehidupan sosial budaya. Ajaran agama akan dipahami pemeluknya sesuai daya nalar, tingkat penga-laman, dan pengaruh lingkungan sekitarnya. Tidak aneh kemudian muncul beragam aliran dan mazhab dalam beragama, walaupun pada dasarnya esensinya sama. Maka lagi-lagi dikatakan bahwa agama pada dasarnya mengandung ajaran dan petunjuk yang ketika bersentuhan dengan nalar, dalam kategori subyektif, akan menghasilkan pola keberagamaan tertentu yang tumbuh dan berkembang dalam masyarakat.

Beragam nalar keberagamaan dapat ditemukan dalam masyarakat Muslim, semisal nalar mistis dimana kepercayaan terhadap alam gaib sangatlah kuat sehingga membentuk norma-norma tertentu di masyarakat yang diikat oleh adanya kekuatan supranatural sebagai kuasa. ${ }^{31}$ Nalar tekstualis dimana pola keberagamaan masyarakatnya didasarkan pada adanya doktrin teks, setiap perbuatan beragama harus selalu dilandasi oleh yang namanya dalil tersurat baik itu dari teks suci ataupun kitab-kitab para salaf yang dinilai otoritatif di bidangnya. ${ }^{32}$ Nalar selanjutnya sering disebut sebagai nalar kritis dimana pola keberagamaan yang telah mapan dan melekat di masyarakat mulai dipertanyakan dan ditelusuri kembali keabsahannya.

Pada dasarnya masih banyak lagi tipologi nalar keberagamaan masyarakat Muslim. Hadirnya tipologi ini sendiri sangat erat kaitannya dengan bagaimana umat Islam 'menggauli' ajaran-ajaran agama yang kemudian termanifestasi dalam wujud perilaku beragama. Latar belakang eksistensialnya sebagai seorang manusia yang hidup di suatu masa dan tempat tertentu sangat mempengaruhi bentuk keberagamaan seorang pemeluk agama.

\footnotetext{
${ }^{30}$ Noor, "Nalar Keislaman Urang Banjar," 187.

31 Noor, 191.

32 A. Halil Thahir, "Dari Nalar Literalis-Normatif Menuju Nalar Kontekstualis-Historis Dalam Studi Islam," ISLAMICA: Jurnal Studi Keislaman 5, no. 1 (2010): 1-14, https://doi.org/10.15642/islamica.2010.5.1.1-14.
} 


\section{Potret Masyarakat Banjar dalam Konteks Sosio-Kultural}

1. Masyarakat Banjar dalam Lintas Waktu

Suku Banjar merupakan salah satu suku terbesar yang mendiami Pulau Kalimantan terutama di Kalimantan Selatan. Masyarakat dari Suku Banjar ini lebih dikenal dengan istilah urang Banjar. M. Suriansyah Ideham mengemukakan bahwa urang Banjar pada awalnya merupakan suku yang mendiami pesisir pantai di Kalimantan Selatan, Timur, dan Tengah. ${ }^{33}$ Di Kalimantan Selatan, pada masa pra-Islam, sebagian besar dari masyarakat Banjar bermukim di sekitar sungai dan daerah rawa. Adapun dua sungai utama dan paling penting bagi masyarakat ini adalah sungai Martapura dan Negara. ${ }^{34}$

Satu hal penting yang perlu disebut pada bagian ini adalah mengenai system kepercayaan masyarakat Banjar pada masa pra-Islam tersebut. Dari sedikitnya keterangan sejarah me-ngenai sistem kepercayaan nenek moyang masyarakat Banjar pada masa kuno, ada satu informasi penting dari Hikajat Bandjar mengenai kerajaan Negaradipa, yakni Empu Jatmika mendirikan candi Agung dan candi Laras yang mengindikasikan kepercayaan Syiwa. ${ }^{35}$ Namun, Alfani Daud memperkirakan bahwa kepercayaan masyarakat Banjar kuno ini adalah animisme berupa pemujaan roh nenek moyang dan hubungan mereka dengan makhluk-makhluk halus. ${ }^{36} \mathrm{Hal}$ ini dapat dibenarkan mengingat mereka tinggal di sekitar sungai dan rawa yang diklaim sebagai tempat tinggal roh-roh halus. Kondisi ini, nampaknya sampai sekarang masih memengaruhi kepercayaan masyarakat Banjar meskipun sudah memeluk kepercayaan yang baru, Islam.

Sebelum era kesultanan berdiri sebagian masyarakat Banjar sudah memeluk Islam, ${ }^{37}$ namun peran Kesultanan Banjar dalam islamisasi bagi perubahan sosio-kultural masyarakat Banjar sangat signifikan. Dengan

${ }^{33}$ M. Suriansyah Ideham et al., Urang Banjar dan Kebudayaannya (Penerbit Ombak, 2015), 72; Wardatun Nadhiroh, "Kitab Sanjata Mu'min: Sebuah Bentuk Tafsir Awam Di Tanah Banjar," SUHUF Jurnal Pengkajian Al-Qur'an Dan Budaya 11, no. 1 (2018): 122.

34 Alfani Daud, Islam dan masyarakat Banjar (RajaGrafindo Persada, 1997).

35 J. J. Ras, Hikayat Banjar (Kuala Lumpur: Dewan Bahasa dan Pustaka Kementerian Pendidikan Malaysia, 1990).

${ }^{36}$ Daud, Islam dan masyarakat Banjar.

37 Ahmadi Hasan, Adat Badamai: Interaksi Hukum Islam dengan Hukum Adat pada Masyarakat Banjar (Banjarmasin: Antasari Press, 2007). 
dibantu ulama besarnya saat itu, yakni Syekh Muhammad Arsyad al-Banjari dan karya monumentalnya Sabilal Mubtadin, kesultanan Banjar menetapkan norma hukum yang berlandaskan adat istiadat sekaligus nilai-nilai ajaran Islam. Fakta ini sebagaimana disebutkan oleh Ahmadi Hasan dalam kesimpulan disertasinya mengenai Adat Badamai pada masyarakat Banjar bahwa Undang-Undang Sultan Adam (UU ini diberlakukan pada masa kekuasaan Sultan Adam al-Watsiq Billah pada tahun 1825-1857) sebagai hukum yang berlaku di kesultanan Banjar kala itu, selain berdasarkan norma adat-istiadat Banjar juga berisikan nilai-nilai ajaran Islam. ${ }^{38}$

Semasa kesultanan Banjar masih ada, struktur sosial masyarakat Banjar dibagi menjadi tiga, yaitu golongan: bangsawan (keturunan raja/sultan), hartawan (orang kaya) dan golongan murba (rakyat jelata). Namun pada perkembangan selanjutnya terjadi pergeseran sistem sosial, disebabkan peran sosial dari golongan bangsawan yang mulai turun, sehingga struktur masyarakat Banjar terbagi menjadi empat golongan, yaitu pegawai peme-rintah/ambtenaar, pedagang, guru/ alim ulama dan golongan petani, yang kesemuanya terikat oleh Islam sebagai identitas sosialnya. ${ }^{39}$ Dalam klasifikasi perilaku beragama, penulis lebih suka memetakan masyarakat Banjar hanya dengan masyarakat biasa dan golongan alim ulama.

Walaupun dinyatakan bahwa masyarakat Banjar tergolong fanatik dalam menjalankan ajaran Islam, namun mereka juga memiliki kepercayaan mistik budaya lokal seperti bagampiran dan memakai jimat-jimat. ${ }^{40}$ Hal senada juga telah ditandaskan Alfani Daud, bahwa urang Banjar diyakini sebagai penganut Islam yang taat, namun dalam ketaatan menjalankan ajaran Islamnya, terdapat kepercayaan dan kelakuan religius yang unsurunsurnya tidak ada dalam referensi Islam, tapi dari kebudayaan lokal. Kelakuan yang dimaksud ini dicontohkan seperti kepercayaan ten-tang 'orang gaib', 'sahabat gaib', upacara kelahiran, kepercayaan tentang tuah benda, upacara kematian, juga tentang 'hari baik' dan 'hari naas'. Menurut Alfani, hal ini merupakan 'pembingkaian' ajaran Islam oleh kebudayaan

\footnotetext{
${ }^{38}$ Hasan.

39 Syaharuddin, Orang Banjar Menjadi Indonesia: Dinamika Organisasi Islam di Borneo Selatan, 19121942 (Yogyakarta: Eja Publisher, 2009).

${ }^{40}$ Nor Ipansyah, Bagampiran dan Pemakaian Jimat dalam Masyarakat Banjar (Banjarmasin: Antasari Press, 2010), 85-87; Nadhiroh, "Kitab Sanjata Mu’min: Sebuah Bentuk Tafsir Awam Di Tanah Banjar," 124.
} 
lokal. ${ }^{41}$ Jadilah yang demikian mengakar menjadi adat-istiadat atau budaya masyarakat Banjar.

Selanjutnya, berbicara tentang falsafah hidup masyarakat Banjar, terfokus untuk memperoleh kualitas ke-sejahteraan. Dari interpretasi Alfani yang dikutip oleh Hadi, pada dasarnya tujuan hidup masyarakat Banjar ada dua, yaitu kesejahteraan di "masa depan yang dekat" dan kesejahteraan di "masa depan yang jauh". ${ }^{42}$ Kesejahteraan di masa depan yang dekat maksudnya adalah hidup sejahtera di dunia, sedangkan kesejahteraan di masa depan yang jauh adalah hidup sejatera di akhirat. Dari kedua macam tujuan tersebut, prioritas utamanya adalah orientasi akhirat.

\section{Islam Banjar sebagai Identitas Keberagamaan}

Perkembangan dan penyebaran Islam di wilayah Kalimantan Selatan sangatlah luas. Data statistik penduduk Kalimantan Selatan tahun 2016 me-nunjukkan bahwa dari jumlah ke-seluruhan masyarakat yang tinggal di Kalimantan Selatan yakni 4.055.479, sekitar 97\% masyarakatnya memeluk agama Islam. Ini menunjukkan bahwa mayoritas penduduk Kalimantan Selatan adalah "Islam" dan "Banjar". Menurut Alfani Daud (Daud, 1997), ini dikarenakan premis bahwa "semua" orang Banjar memeluk Islam, bahkan jika ada orang Dayak yang memeluk Islam akan dianggap "menjadi orang Banjar". ${ }^{43}$ Sementara menurut antropolog Judith Nagata yang dikutip Hairus Salim HS sebagai kata pengantar buku Ahmad Gaus AF, menyatakan bahwa Banjar merupakan salah satu suku di Indonesia yang identitas kesukuannya bertumpang tindih dengan identitas keagamaan, "agama ya suku, suku ya agama". ${ }^{4}$

Direktorat Sejarah dan Nilai Tradisional Kalimantan Selatan (1985), sebagaimana dikutip Nadhiroh, mengemukakan bahwa suku Banjar merupakan suku yang menanamkan muatan-muatan Islam dalam setiap

${ }^{41}$ Daud, Islam dan masyarakat Banjar, 581-92.

42 Sumasno Hadi, "Studi Etika Tentang Ajaran-Ajaran Moral Masyarakat Banjar," Tashwir, Jurnal Penelitian Agama Dan Sosial Budaya 3, no. 6 (2015): 216, https://doi.org/10.18592/jt.v3i6.594.

43 Daud, Islam dan masyarakat Banjar, 5; Nadhiroh, "Kitab Sanjata Mu'min: Sebuah Bentuk Tafsir Awam Di Tanah Banjar,” 124.

${ }^{44}$ F, Sang pelintas batas, xi-xxii; Supriansyah, "Agresi Kultur Digital dan Konsumerisme ada Identitas Urang Banjar di Era Pascamodern.” 
perilaku mereka bahkan dalam hal-hal yang bersifat sosial budaya ${ }^{45}$ Ajaran Islam dijalankan dengan patuh oleh urang Banjar. Karena itulah di Kalimantan Selatan banyak sekali ditemui masjid dan langgar/surau. Kegiatan keagamaan seperti pengajian dan kuliah agama juga banyak dilaksanakan, terlebih jika pada bulan Ramadhan hingga Idul Fitri. Oleh karena itulah, dalam masyarakat Banjar dikenal istilah 'Islam Banjar' karena agama Islam yang dianut masyarakat Banjar tidak berhenti pada institusi kepercayaan saja, melainkan sudah melebur pula pada tata kehidupan sehari-hari, dalam adat istiadat yang dianut dan dilaksanakan oleh masyarakat setempat.

Terintegrasinya agama Islam dalam kehidupan sehari-hari masyarakat Banjar, salah satunya dapat dilihat dari siklus hidup masyarakatnya yang disesuaikan dengan penanggalan Hijriah. Penyebutan bulan Arab untuk penanda waktu seperti Mubarram, Safar, Rabi'ul Awwal, Rabi'ul Akbir, Jumadil Awwal, Jumadil Akbir, Rajab, Sya'ban, Ramadan, Syawwal, Dzul Qa'dah, dan Dzulbijjah. ${ }^{46}$ Penggunaan nama hari yang sering muncul dalam percakapan sehari-hari juga menggunakan penamaan Arab, bahkan sampai nama pasar-pasar di daerah Banjar pun dinamai dengan hari dalam kalender Arab, semisal Pasar Arba' karena dilaksanakan setiap hari Rabu dan Pasar Ahad yang dilaksanakan setiap hari Minggu. Penanaman nilai-nilai agama, seperti dakwah dan pengajian di masjid tidak pernah sepi. Begitu pula kegiatan belajar mengaji yang dilakukan oleh anak-anak di masjid dengan satu guru maupun dengan memanggil guru mengaji ke rumah merupakan salah satu kegiatan yang tidak ditinggalkan. Pelaksanaan rukun Islam seperti zakat dan keinginan untuk melaksanakan ibadah haji maupun melaksanakan umrah juga tumbuh dengan sangat subur di Kalimantan Selatan. Para peminat untuk naik haji dan umrah selalu meningkat tiap tahunnya. Bahkan yang sudah pernah haji dan umrah sekali masih merasa kurang, sehingga berangkat berkali-kali.

Dengan kultur keberagamaan yang demikian, maka pada akhirnya alim ulama memegang posisi terpenting dalam penyebaran dan pengajaran Islam di tanah Banjar. Bahkan hingga sekarang, para alim ulama yang sering

\footnotetext{
${ }^{45}$ Nadhiroh, "Religious and Gender Issues in the Tradition of Basurung and the Polygamy of Banjar Tuan Guru in South Kalimantan," 267.

${ }^{46}$ Hadi, "Studi Etika Tentang Ajaran-Ajaran Moral Masyarakat Banjar," 216.
} 
disebut dengan istilah tuan guru ${ }^{47}$ di Banjar ini menjadi panutan dalam kehidupan sehari-hari. Apa yang mereka anjurkan, niscaya akan dilakukan oleh masyarakat Banjar. Kalangan yang menjadi tokoh sentral dalam kehidupan beragama masyarakat Banjar dihormati karena ketinggian ilmunya, keterpujian akhlak, kesalehan, dan peranan konkret yang mereka lakukan dalam membina masyarakat. Kedudukan mereka sangat tinggi dalam struktur masyarakat Banjar. Kedatangannya disambut, dihormati, dijabat bahkan dicium tangannya.

Para tuan guru ini selalu menjadi tempat kembali segala permasalahan yang dihadapi masyarakat, baik itu menyangkut permasalahan agama maupun persoalan lainnya yang terjadi dalam kehidupan sehari-hari. Perkara yang paling banyak dikonsultasikan adalah tentang pembagian harta waris, perkawinan, hutang-piutang, dan masalah ibadah. Lainnya adalah masalah yang berkaitan dengan kehidupan keluarga (hubungan suami-istri, kenakalan anak, konflik orang tua-anak, konflik menantumertua, termasuk perkara jodoh), masalah hidup keseharian seperti pekerjaan (belum mendapat pekerjaan tetap, kesiapan menerima tawaran pekerjaan, ketakseimbangan antara pendapatan dan pengeluaran), dan ketidakharmonisan hidup bertetangga. Bahkan ada juga masyarakat yang berkonsultasi untuk masalah pengobatan spiritual atau penyembuhan (fisik) atau gangguan (mental). ${ }^{48}$ Para pejabat yang hendak mencalonkan diri pun, tidak afdhal jika belum meminta 'restu' pada tuan guru. ${ }^{49}$ Hajatan tak akan

${ }^{47}$ Di Kalimantan Selatan, ulama disebut guru, mu'allim (informal), dan tuan guru untuk sebutan formal. Lihat: Abdul Djebar Hapip, Kamus Banjar-Indonesia (Jakarta: Pusat Pembinaan dan Pengembangan Bahasa, Departemen Pendidikan dan Kebudayaan, 1977). Istilah tuan guru dalam budaya Banjar merujuk pada orang-orang yang memiliki kapasitas keilmuan agama yang luas dan mumpuni. Sebutannya tersebut setara dengan istilah kyai di Pulau Jawa. Yang mungkin membedakannya adalah tuan guru di Banjar tidak harus mempunyai pesantren, namun mereka memiliki jamaah pengajian atau majelis ta'lim. Di Banjar, penyebutan tuan guru hanya dialamatkan untuk seorang laki-laki yang memiliki kecakapan dan keluasan ilmu, terutama ilmu agama, yang itu diakui oleh orang-orang di sekitarnya. Walaupun banyak juga perempuan Banjar yang memiliki keilmuan yang tinggi, tidak ada satupun yang menyandang gelar tuan guru.

48 Makmur, "Peranan Ulama Dalam Membina Masyarakat Banjar Di Kalimantan Selatan," 181; Nadhiroh, "Religious and Gender Issues in the Tradition of Basurung and the Polygamy of Banjar Tuan Guru in South Kalimantan," 268-69.

${ }^{49}$ Nadhiroh, "Religious and Gender Issues in the Tradition of Basurung and the Polygamy of Banjar Tuan Guru in South Kalimantan," 269. 
terlaksana tanpa kedatangan tuan guru sebagai inti acara. Maka pada akhirnya, ulama atau tuan guru tidak hanya menjadi seorang pemuka agama tetapi juga mengambil fungsi sebagai pemimpin kemasyarakatan.

Dengan fenomena keberagamaan yang demikian, nampaknya masyarakat Banjar memiliki suatu 'ketergantungan' terhadap sosok tuan guru. Bahkan tidak hanya semasa hidupnya para tuan guru ini dihormati, bahkan setelah wafatnya, makam para ulama ini masih ramai dikunjungi karena dipercayai mereka mempunyai karamah. ${ }^{50}$ Di satu sisi, memang kesadaran akan adanya kebutuhan untuk selalu mendapatkan petuah dan siraman-siraman spiritual dari tuan guru sebagai pemuka umat merupakan suatu hal yang baik, namun ketika kesadaran menjadi suatu keter-gantungan ini dirasa sampai pada tahap mengidolakan secara membabi buta, tentu akan memberikan citra negatif pada wajah Islam di Banjar.

\section{Tipologi Nalar Masyarakat Banjar dalam Beragama; Dari Masa ke Masa}

1. Masa Pra-Islam

Sebagaimana dapat ditemukan di hampir seluruh Nusantara, secara umum, kepercayaan yang berkembang di Kalimantan Selatan adalah animisme dan dinamisme. Kedua kepercayaan ini meyakini adanya kekuatan-kekuatan gaib yang termanifestasi dalam alam roh. Kepercayaan akan adanya kekuatan gaib dalam kenyataan pengalaman ini disebut Berger sebagai mitos. ${ }^{51}$

Pada masa ini, pola keberagamaannya dilandasi oleh nalar mistis yang dibangun dari mitos atau keyakinan akan kekuatan supranatural tertentu yang menguasai dunia. Dalam nalar ini, masyarakat meyakini bahwa dimensi ideologis keberagamaan mereka tak terlepas dari peran roh-roh gaib, baik itu yang dianggap baik ataupun jahat karena dipercayai mampu menimbulkan dampak tertentu dalam kehidupan sehari-hari mereka. Dikatakan bahwa roh-roh tersebut bersemayam di tempat-tempat tertentu seperti batu besar, pohon besar, atau tempat khusus lainnya. Para roh ini dapat bergentayangan mengganggu manusia sehingga untuk menghindari hal-hal yang tidak diinginkan dari gangguan para roh ini disediakan sesaji

\footnotetext{
${ }^{50}$ Nadhiroh, 269.

${ }^{51}$ Peter L. Berger, Tafsir Sosial atas Kenyataan: Risalah tentang Sosiologi Pengetabuan (Jakarta: LP3ES, 1990), 6.
} 
dalam bentuk makanan dan minuman pada waktu tertentu sebagai bentuk penghormatan kepada mereka. ${ }^{52}$

Fenomena keberagamaan masa ini juga hadir dalam bentuk mengeramatkan benda-benda tertentu. Dipercaya bahwa ada roh yang bermukim pada suatu benda yang jika dijaga dengan baik maka akan membantu pemilik benda tersebut dengan tuah yang tersimpan di dalamnya. Biasanya barang-barang keramat seperti ini disebut wasi tuha, wujudnya bisa berupa keris, tombak, parang, cemeti, maupun lainnya. ${ }^{53}$ Belum lagi jimat dan mantra sebagai sebagai cara menangkal kejahatan ataupun untuk mengirimkan kekuatan jahat kepada seseorang.

Secara epistemologi, pengetahuan keagamaan masa pra-Islam ini dibangun dari mitologi-mitologi yang berkembang di masyarakat. Keberagamaannya dilandasi oleh orientasi akan keselamatan hidup di dunia, selama tidak ada gangguan dari roh, maka kehidupan sejahtera akan tercapai. Nalar mistis hadir meliputi seluruh dimensi keberagamaan masyarakat Banjar pra-Islam.

Dalam perkembangan selanjutnya, animisme dan dinamisme sebagai budaya lokal bertemu dengan Buddhisme dan Hinduisme yang dibawa oleh para imigran. Buddhisme dan Hinduisme semakin kokoh seiring berdirinya kerajaan Tanjungpura(i) dan Negara Dipa. Tidak ada sumber tertulis yang menguraikan perihal keagamaan yang berkembang pada masa itu, na-mun adanya peninggalan Candi Agung dan Candi Laras memberikan bukti akan adanya suatu keagamaan karena candi biasa digunakan sebagai tempat ibadah agama Hindu. ${ }^{54}$

Adanya pergeseran nilai-nilai keramat yang dulu hadir dalam kepercayaan animisme dan dinamisme ke Hindu-Buddha dapat ditelusuri dari mitos yang terbungkus cerita rakyat Banjar yang itu masih hadir sampai sekarang. Salah satu mitos masyarakat Banjar yang terkenal adalah tentang Putri Junjung Buih. ${ }^{55}$ Dalam mitos itu, diceritakan bahwa Mpu Jatmika sebelum wafat berwasiat kepada kedua anaknya Lambung Mangkurat dan Mpu Mandastana agar jangan berniat untuk menjadi raja, sebab mereka

\footnotetext{
${ }^{52}$ Noor, "Nalar Keislaman Urang Banjar," 191.

53 Ahmad Basuni, Nur Islam Di Kalimantan Selatan: Sejarah Masuknya Islam Di Kalimantan (Bina Ilmu, 1986), 48.

${ }^{54}$ Noor, "Nalar Keislaman Urang Banjar," 192.

55 Ideham et al., Urang Banjar dan Kebudayaannya, 29-30.
} 
bukanlah keturunan raja. Mpu Jatmika sendiri hanya menganggap dirinya sebagai raja sementara, sebab yang dianggap sebagai raja pertama adalah patung dirinya yang terbuat dari kayu cendana. Patung inilah yang disembah oleh rakyat sebagai raja. Konon itu dilakukan untuk menghindari kutukan karena Mpu Jatmika tak pantas menjadi raja karena bukan keturunan raja. Karena itu ia menyuruh Lambung Mangkurat pergi bertapa untuk mencari raja yang sah. Pasca wafat ayahnya, Lambung Mangkurat melakukan tapa brata (balampah) di sebuah sungai. Ketika sedang bertapa, tiba-tiba di pusaran air keluar buih yang bersinar, lalu muncul seorang puteri. Puteri itu kemudian diberi nama Putri Junjung Buih (puteri dari buih yang dimuliakan) dan diangkat menjadi ratu di Negara Dipa. Begitupun juga suami Puteri Junjung Buih, Pangeran Suryanata diperoleh Lambung Mangkurat melalui tapa brata. ${ }^{56}$

Cerita tersebut menunjukkan bentuk kepercayaan lokal, roh-roh keramat yang bersifat metafisik dan mengambil tempat di benda padat sebagai tempat bersemayam mengalami pergeseran seiring pengaruh Hindu-Buddha, yang mana nilai-nilai keramat tersebut berubah menjadi pribadi-pribadi (yang dianggap) suci seperti Putri Junjung Buih dan Pangeran Suryanata. Walaupun dalam batas-batas tertentu pola animisme dan dinamisme tidak sepenuhnya sirna. Itu terlihat dari keberadaan patung Mpu Jatmika yang disembah. ${ }^{57}$

Personifikasi kekeramatan pada pribadi dalam cerita di atas menunjukkan adanya struktur nalar Hindu. Dalam Upanisad ada ajaran tentang hubungan antara Atman dan Brahman, mikrokosmos dan makrokosmos. Tapa brata atau yoga dalam ajaran Hindu adalah jalan penghubung antara keduanya. Dalam artikelnya, Iqbal menjelaskan bahwa Putri Junjung Buih dan Pangeran Suryanata sebagai hasil tapa brata merupakan lambang kesatuan antara atman dan brahman, mikrokosmos dan makrokosmos karena keduanya merupakan perpanjangan tangan —untuk tidak mengatakan inkarnasi- Tuhan untuk menata dunia fana. ${ }^{58}$

Selain itu, pola beragama yang awalnya, dalam kepercayaan animisme dan dinamisme, terfokus pada pemberian sesaji ketika mengharapkan sesuatu atau menghindari gangguan, ketika Hindu-Budha datang,

\footnotetext{
${ }^{56}$ Ideham et al., 29-30.

${ }^{57}$ Noor, "Nalar Keislaman Urang Banjar," 192.

${ }^{58}$ Noor, 192-93.
} 
pergeseran terjadi dengan mengandalkan diri sebagai perantara dan melakukan bentuk tapa untuk tujuan tertentu. Pada masa awal ini, nalar keberagamaan masyarakat Banjar yang berkembang adalah mistis-realis yang bergeser menjadi mistis-idealis seiring dengan kedatangan HinduismeBudhisme.

2. Masa Kesultanan Banjar

Menurut H. Gt. Abdul Muis, agama Islam masuk ke daerah Kalimantan Selatan sekitar permulaan abad ke 16 M dibawa oleh para pedagang dan mubaligh lewat pantai utara Jawa Timur. ${ }^{59}$ Islam sebenarnya sudah mulai dianut oleh sebagian masyarakat sebelum berdirinya Kerajaan Banjar, namun setelah kerajaan Banjar berdiri, maka seluruh masyarakatnya memeluk Islam, karena Islam dijadikan agama resmi kerajaan, dan perkembangan agama Islam pun berkembang pesat sekali. Sejak itu pula masyarakat meninggalkan kepercayaan sebelumnya yakni animisme maupun Hindu. Pangeran Samudera sebagai raja pertama memakai nama dan gelar baru yakni Sultan Suriansyah, dan semenjak itu pula muncul istilah kesultanan Banjar. ${ }^{60}$

Lebih jauh Ahmad Bardjie menguraikan bahwa se-menjak Sultan Suriansyah, beberapa langkah islamisasi dilakukan antara lain mendorong agar adanya pengkaderan ulama mengingat ulama pada waktu itu masih sedikit. Sultan Tamjidillah I mengirim Muhammad Arsyad al-Banjari untuk belajar ke Mekkah yang sepulangnya menjadi ulama dan berdakwah yang dipusatkan di kampung Dalam Pagar Martapura. Ke sinilah para penuntut ilmu berdatangan, selain dari Martapura juga berdatangan dari Banjarmasin, Nagara dan dari Hulu Sungai. Selain memfasilitasi tempat pengajian para ulama, Sultan juga mendorong ulama agar aktif membimbing umat secara tertulis, maka ulama seperti Syekh Muhammad Arsyad didorong menulis buku/kitab sebagai pegangan umat. ${ }^{61}$

Sosok Muhammad Arsyad dapat dikatakan sebagai sentral keberagamaan masyarakat Banjar saat itu. Walaupun karya-karya beliau yang dapat ditemukan semisal Tubfah al-Raghibin dan Sabil al-Mubtadin lebih

\footnotetext{
${ }^{59}$ Analiansyah, Aspirasi Pendidikan Masyarakat Banjar (Banjarmasin: Antasari Press, 2007), 8.

${ }^{60}$ Kamrani Buseri, "Kesultanan Banjar Dan Kepentingan Dakwah Islam," Al-Banjari: Jurnal Ilmiah Ilmu-Ilmu Keislaman 11, no. 2 (2012): 221, https://doi.org/10.18592/al-banjari.v11i2.457.

${ }^{61}$ Ahmad Bardjie, Refleksi Banua Banjar: Kumpulan Tulisan Seputar Kesultanan Banjar, Sejarah, Agama, Dan Sosial Budaya (Martapura: Pustaka Agung Kesultanan Banjar, 2011), 6-8.
} 
menyorot pada bidang akidah dan syari'ah, bukan berarti beliau awam dengan tasawuf. Beliau adalah teman seperguruan Abd al-Shamad alPalimbani, pengarang kitab tasawuf berbahasa Melayu, Hidayat al-Salikin dan Sair al-Salikin, serta murid dari pendiri Tarekat Sammaniyah, Muhammad Samman al-Madani (1719-1775). Tentunya keilmuan beliau di bidang tasawuf tidak perlu diragukan, walaupun pada faktanya, beliau lebih suka mengajarkan masalah akidah dan syari'ah karena beliau berdakwah untuk masyarakat awam yang baru mempelajari Islam. ${ }^{62}$ Dalam hal ini, Syekh Arsyad mengusung faham neo-sufisme yang berarti harmonisasi antara ajaran syariat dan tasawuf. ${ }^{63}$ Secara tegas beliau menyatakan diri sebagai pengikut Abl al-Sunnah wa al-Jama'ah yang itu dikatakan beliau sebagai i'tikad Nabi, para Sahabat, tabi'in, tabi'i al-tabi'in dan i'tikad yang benar sampai kiamat. ${ }^{64}$

Di masa ini, penulis menilai bahwa pola keberagamaan masyarakat Banjar adalah ulama sentris dimana ulama tidak hanya berperan dalam penyebaran dan pengajaran agama Islam, tetapi juga sebagai penasihat pemerintahan saat itu sebagaimana yang dilakukan oleh Syekh Arsyad alBanjari. Melihat kenyataan bahwa walaupun Syekh Arsyad menguasai ilmu tasawuf dengan sangat baik, namun hal tersebut tidak diajarkan dalam pengajian beliau, ini dimungkinkan karena rasa kekhawatiran akan menimbulkan kesalahpahaman dalam beragama. Ini untuk menghindari terjadinya peristiwa yang menimpa Syekh Abdul Hamid Abulung terulang di masyarakat. Walaupun konsep wahdatul wujudnya, dalam ranah tasawuf, dapat diterima, namun hal ini tidak berlaku bagi masyarakat Banjar awam yang baru memahami dasarnya saja sehingga akhirnya sang syekh harus dihukum mati karena dianggap menyalahi agama. ${ }^{65}$

Masa kesultanan Banjar dapat disebut sebagai masa transisi keberagamaan dimana terjadi konversi keyakinan masyarakat Banjar yang

62 Mujiburrahman Mujiburrahman, "Tasawuf di Masyarakat Banjar: Kesinambungan dan Perubahan Tradisi Keagamaan," Kanz Philosophia : A Journal for Islamic Philosophy and Mysticism 3, no. 2 (2013): 153-83, https://doi.org/10.20871/kpjipm.v3i2.46.

${ }^{63}$ Bardjie, Refleksi Banua Banjar: Kumpulan Tulisan Seputar Kesultanan Banjar, Sejarah, Agama, Dan Sosial Budaya.

${ }^{64}$ Amin Syukur, Pemikiran-pemikiran Syekh Mubamad Arsyad al-Banjari dalam Bidang Taubid dan Tasawuf (Center for Community Development Studies Kalimantan, 2009).

${ }^{65}$ Ideham et al., Urang Banjar dan Kebudayaannya, 49-53. 
awalnya beragama leluhur, Hindu, dan Budha, kemudian beralih menjadi Islam sehingga masyarakatnya pun masih awam dengan ajaran Islam. Dengan pertimbangan keawaman ini, ulama saat itu hanya mengajarkan masalah akidah dan syari'ah saja agar dikehendaki masyarakat Banjar memiliki dasar yang kuat terlebih dahulu dalam beragama sementara persoalan-persoalan khilafiyah ditinggalkan. Ulama Banjar akhirnya hanya mengajarkan Islam secara normatif saja dengan bersumber apa yang tersurat dari nash-nash dan kitab salafusshalih.

Pengajaran agama yang sifatnya literal-normatif tadi akhirnya melahirkan paham keberagamaan yang tradisionalis bagi masyarakat Banjar sehingga pada akhirnya apa yang diajarkan oleh ulama, itu pula yang mereka terima dan kerjakan dalam perilaku beragama tanpa ada upaya mempertanyakannya. Tradisi ini awet berkembang dalam tradisi keberagamaan masyarakat Banjar bahkan hingga munculnya gerakan keagamaan.

Namun, bukan berarti tradisi mistik yang menjadi warisan di masa sebelumnya hilang serta merta, namun adanya upaya untuk mengakomodasi praktek tersebut dengan budaya Islam. Pemberian sesaji untuk roh yang diletakan di tempat-tempat tertentu diganti dengan budaya selamatan dengan membacakan doa yang dipimpin tuan guru dan kemudian hidangannya pun dinikmati bersama. Adapun perilaku tapa sebagai perilaku ritual untuk memohon petunjuk diganti dengan ajaran shalat yang khusyuk dan berdoa dalam Islam.

Pada dasarnya, dalam Islam pun nalar mistik berkembang dalam dunia tasawufnya. Bahkan seorang Muhammad Arsyad pun juga seorang sufi. Namun karena nalar mistik sufi dalam Islam lebih mementingkan sisi bathinnya, kesiapan ini dirasa belum dapat dipenuhi oleh masyarakat awam Banjar. Konsep kesadaran yang ada hanyalah Allah tidak dapat dipahami logika kebanyakan karena dalam pemahaman tasawuf, pengetahuan sejati itu hanya milik Allah. Pengetahuan itu juga hanya dapat didapat langsung dari Allah secara intuitif atau disebut juga kasyf. Dalam masyarakat Banjar, dikenal ajaran "shalat daim" atau "ilmu sabuku" yaitu ajaran shalat sekali untuk seumur hidup. ${ }^{66}$ Shalat yang dimaksud dalam nalar mistik berada pada ide yakni kesadaran akan Tuhan secara terus-menerus, bukan maksud shalat yang disyariatkan Islam selama ini yang diatur dan ditentukan.

${ }^{66}$ Syafruddin and Syahriansyah, Ajaran Tasawnf Syekh Hamid Abulung (Yogyakarta: Sumbangsih Press, 2007). 
Jadi, pada masa Kesultanan Banjar dimana Islam mulai memapankan dirinya dalam kehidupan bermasyarakat, pola keberagamaan masyarakatnya cenderung menggunakan nalar normatif yang menjadikan ulama sebagai sumber pengetahuan awal sehingga dogma dan ritual-ritual keagamaan mengikuti pengajaran ulama tersebut. Walaupun kebanyakan ulama di masa ini mengajarkan akidah dan syari'at, namun bukan berarti mereka bukan seorang pelaku tasawuf. Kehidupan tasawuf mereka disimpan untuk pribadi saja karena jika disebarkan untuk masyarakat umum dikhawatirkan menimbulkan kesalahpahaman dalam beragama.

3. Pasca Masuknya Gerakan Keagamaan

Selepas pemerintahan dengan kesultanan Banjar sebagai porosnya runtuh, nasib penyebaran agama Islam ada di tangan ulama. Dalam sejarah di-katakan bahwa ratusan tahun keturunan Syekh Arsyad al-Banjari yang menjadi agen sentral dakwah di bumi Banjar ini. Dikarenakan peran dan jasanya yang begitu mulia sepanjang sejarah Islam di Banjar, sampai sekarang kedudukan ulama atau tuan guru masih sangat tinggi dan terhormat dalam masyarakat, bahkan bisa dibilang "apa-apa ke tuan guru" semua perkara dikonsultasikan dan dimintai pertimbangan kepada ulama. Pada tahapan ini, pola keberagamaan yang tradisionalis melekat erat dalam budaya masyarakat Banjar.

Pasca Indonesia merdeka, ber-bagai gerakan keagamaan semakin menjamur dan menyebar dalam ke-hidupan bermasyarakat Indonesia, sebut saja Nahdhatul Ulama (NU), Muhammadiyah, Persatuan Islam (PERSIS), dan al-Washliyah adalah beberapa organisasi keagamaan yang dikatakan adalah asli milik Indonesia. Tanah Banjar pun tak terlepas dari 'serbuan' orga-nisasi ini, walaupun hanya NU dan Muhammadiyah yang berkembang dan mendapatkan pengikutnya.

Namun faktanya, organisasi NU lah yang paling banyak menarik minat masyarakat Banjar karena golongan ini masih menerima tradisitradisi kelo-kalan yang kemudian diakomodir ke dalam agama Islam sebagai bagian dari syari'at. Visi yang sama dengan yang telah ada sebelumnya di masa kesul-tanan Banjar. Belum lagi dari namanya saja sudah ada indikasi bahwa NU akan lebih diterima dibanding lainnya me-ngingat masyarakat Banjar sangat memuliakan sosok ulama, untuk tidak mengatakan 'mendewakan'nya. Karena kesamaan prinsip NU yang berdasarkan Ahlu alSunnah wa al-Jama'ah maka gerakan keagamaan ini diterima dengan terbuka oleh masyarakat Banjar. Maka menurut Sarmadi, jadilah NU 
sebagai wadah keyakinan keberagamaan umumnya masyarakat Banjar. ${ }^{67}$ Meskipun tidak menafikan mereka yang beraliran kemuhammadiyahan.

Jika sebelumnya pengajaran keilmuan Islam yang dilakukan Syekh Arsyad hanyalah bertempat di majlis pengajian, dimana masyarakat yang ingin menimba ilmu hadir pada waktu tertentu kemudian pulang, beberapa generasi kemudian bermunculan pusat pengajaran ilmu keislaman dalam ben-tuk pondok pesantren dimana masya-rakat dapat sehari bahkan seharisema-lam menimba ilmu agama di sana di-karenakan ada keharusan mukim di sana. Di Kalimantan Selatan, tercatat ada 241 buah pondok pesantren, 90\% bersifat modern dan hampir kesemuanya berlatar belakang NU. Fanatisme terhadap NU bagi masyarakat Banjar kesemuanya didasarkan pada ketaatan pada kyai atau tuan guru, dimana sang kyai biasanya merupakan pimpinan pondok pesantren yang merepresentasikan diri sebagai orang NU. ${ }^{68}$

Maka mengingat dalam masa sebelumnya, pola keberagamaan masyarakat Banjar adalah ulama sentris, masuknya gerakan keagamaan NU semakin mempertegas yang dimaksud adalah ulama NU sentris. Tradisi lokal Banjar seperti batapung tawar tetap dilestarikan tetapi diiringi doa, acara haul kematian dilestarikan dan diisi dengan pembacaan doa arwah, serta masih banyak lagi produk lokal peninggalan leluhur yang kemudian diakomodir dan diberi nuansa Islam. Bahkan pola mistik yang dulu berkembang di masa Pra-Islam seperti penggunaan jimat untuk jaga diri diganti dengan pembacaan ayat al-Qur'an, mantra berganti menjadi doa dan ayat al-Qur'an dan lain sebagainya. Di tangan NU, tradisi lokal yang dimasuki nuansa Islam ini semakin berkembang dan berakar dalam kehidupan masyarakat Banjar.

Dengan tradisi kultural NU yang demikian, maka pendapatpendapat keagamaan yang bersifat baru dan terlihat berbeda atau berlawanan dengan tradisi dan fatwa ulama atau tuan guru akan ditepis. Isu tentang gender, persamaan hak perempuan dan laki-laki, HAM, tidak

\footnotetext{
${ }^{67}$ Ahmad Sukris Sarmadi, "NU Dalam Bingkai Masyarakat Banjar: Arah Pergerakan Islam Kultural Dan Islam Non Kultural Di Kalimantan Selatan,” Jurnal Theologia 21, no. 1 (2010); A. Sukris Sarmadi, "Transformasi NU Dalam Masyarakat Banjar Kini Perspektif Pergeseran Gerakan Keagamaan Di Kalimantan Selatan,” Dialog 32, no. 2 (2009): 26.

${ }^{68}$ Sarmadi, "Transformasi NU Dalam Masyarakat Banjar Kini Perspektif Pergeseran Gerakan Keagamaan Di Kalimantan Selatan,” 26-27.
} 
berpengaruh bagi masyarakat Banjar yang lebih tertarik pada nasehat kyai atau tuan guru. ${ }^{69}$

Nalar keberagamaan tradisionalis masyarakat Banjar ini sedikit mengalami pergeseran dengan bermunculannya institusi pendidikan agama resmi berupa perguruan tinggi agama Islam (baca: IAIN) dimana di sana mulai ditekankan untuk berpikir kritis dan logis mengingat pengajaran yang diberikan tidak melulu agama tetapi dibekali dengan pengetahuan umum juga. Para alumni perguruan tinggi inilah yang mulai mewarnai pola keberagamaan masyarakat Banjar yang awalnya sangat tradisionalis, dengan nalar literalis-normatif, mulai membuka diri untuk bersikap kritis dalam doktrin-doktrin keagamaan yang selama ini telah tertanam kuat dalam tradisi beragama masyarakat Banjar.

Namun nalar beragama kritis ini juga belum merata tersebar ke seluruh masyarakat Banjar. Kebanyakan tokohnya berada di Banjarmasin, sementara di Banua Lima sangat minim ditemui sehingga tetap saja nalar tradisionalis dalam beragama masih berakar kuat di masyarakat Banjar.

Di abad 20 hingga sekarang, seiring dengan arus modernisasi yang mewarnai dunia, beragama aliran keagamaan baru muncul yang menamakan dirinya sebagai gerakan pe-murnian Islam, baik itu Jama'ah Tabligh, HTI, dan yang terbaru adalah gerakan Salafi. Kesemua gerakan yang ingin mengembalikan ajaran Islam kepada nash al-Qur'an, Hadis, dan tradisi salafussalih.

Di Kalimantan Selatan, gerakan-gerakan demikian juga melebarkan sayapnya dan mendapatkan pengikut. Walaupun dibilang sebagai aliran baru dan pengikutnya sedikit, namun gerakan ini mampu menarik perhatian masyarakat Banjar. Terutama untuk gerakan terakhir yang disebutkan, yakni Salafi sangat gencar dalam menyebarkan paham-paham keberagamaannya. Bagi kalangan ini, tradisi lokal Banjar yang telah distempel NU sebagai bagian dari Islam dianggap bid'ah yang tidak diperbolehkan untuk diamalkan. Tentunya ini membuat reaksi keras dari kalangan NU. Sebagai mayoritas tentunya NU memiliki kuasa dalam menentukan pola keberagamaan masyarakat di Banjar, namun diakui atau tidak sedikit demi sedikit pengikut gerakan ini semakin bertambah. Dimungkinkan jika fenomena ini dibiarkan, maka akan terjadi lagi pergeseran nalar beragama masyarakat Banjar.

\footnotetext{
${ }^{69}$ Sarmadi, 28.
} 


\section{Mapping Singkat Tipologi Nalar Masyarakat Banjar dalam Beragama}

Dari tipologi nalar keberagamaan masyarakat Banjar dari masa ke masa di atas, dapat dipetakan menjadi sebagai berikut

\begin{tabular}{|c|c|c|c|c|}
\hline \multirow[b]{2}{*}{ Masa } & \multicolumn{2}{|c|}{ Pra-Islam } & \multirow{2}{*}{$\begin{array}{c}\text { Masa } \\
\text { Kesultanan } \\
\text { Banjar }\end{array}$} & \multirow{2}{*}{$\begin{array}{c}\text { Pasca } \\
\text { Masuknya } \\
\text { Gerakan } \\
\text { Keagamaan }\end{array}$} \\
\hline & $\begin{array}{l}\text { Animisme- } \\
\text { Dinamisme }\end{array}$ & $\begin{array}{l}\text { Hinduisme- } \\
\text { Buddhisme }\end{array}$ & & \\
\hline Nalar & Mistis Realis & Mistis Idealis & Literalis-Normatif & $\begin{array}{c}\text { Tradisional- } \\
\text { Kritis }\end{array}$ \\
\hline Ideologis & $\begin{array}{c}\text { Alam roh } \\
\text { mempengaruhi } \\
\text { kehidupan } \\
\text { manusia }\end{array}$ & $\begin{array}{c}\text { Adanya kuasa } \\
\text { gaib yang } \\
\text { dapat } \\
\text { menjelma }\end{array}$ & $\begin{array}{c}\text { Islam dogmatis } \\
\text { dengan semboyan } \\
\text { Aswaja }\end{array}$ & Islam NU \\
\hline Intelektual & $\begin{array}{l}\text { Mitos sebagai } \\
\text { sumber } \\
\text { pengetahuan }\end{array}$ & $\begin{array}{l}\text { Tapa untuk } \\
\text { meminta } \\
\text { petunjuk }\end{array}$ & Ulama sentris & $\begin{array}{c}\text { Ulama NU } \\
\text { sentris }\end{array}$ \\
\hline Eksperiensial & $\begin{array}{c}\text { Ketakutan } \\
\text { akan kekuatan } \\
\text { supranatural }\end{array}$ & Konfirmatif & Agamis & $\begin{array}{c}\text { Fanatisme tuan } \\
\text { guru }\end{array}$ \\
\hline Ritualistik & $\begin{array}{l}\text { Pemujaan dan } \\
\text { pemberian } \\
\text { sesaji benda- } \\
\text { benda tertentu }\end{array}$ & $\begin{array}{c}\text { Tapa atau } \\
\text { mengasingkan } \\
\text { diri untuk } \\
\text { berdoa }\end{array}$ & $\begin{array}{l}\text { Taat menjalankan } \\
\text { apa yang tersurat } \\
\text { diperintahkan } \\
\text { agama melalui } \\
\text { pengajaran ulama }\end{array}$ & $\begin{array}{c}\text { Taat } \\
\text { menjalankan } \\
\text { perkataan } \\
\text { ulama, kyai atau } \\
\text { tuan guru. }\end{array}$ \\
\hline Konsekuensial & $\begin{array}{c}\text { Individualis } \\
\text { mementingkan } \\
\text { keselamatan } \\
\text { pribadi }\end{array}$ & $\begin{array}{l}\text { Beragama } \\
\text { tidak hanya } \\
\text { untuk diri } \\
\text { sendiri }\end{array}$ & $\begin{array}{c}\text { Terkesan } \\
\text { individualis dalam } \\
\text { beragama }\end{array}$ & $\begin{array}{c}\text { Saling } \\
\text { membanggakan } \\
\text { diri dalam } \\
\text { beragama }\end{array}$ \\
\hline
\end{tabular}

Pada dasarnya, tipologi di atas itu tidak baku dan pasti karena dalam perkembangan nalar kekeberagamaan masyarakat Banjar tidak terjadi evolusi linier, namun lebih bersifat overlapping. Penulis mengambil istilah yang digunakan Iqbal karena memang di masa selanjutnya, nalar sebelumnya tetap ada walaupun yang menggunakannya bukan kalangan mayoritas. ${ }^{70}$ Yang penulis inginkan dari tipologi ini adalah menunjukkan adanya pergeseran nalar beragama masyarakat Banjar dari waktu ke waktu, yang masih akan bergerak

\footnotetext{
${ }^{70}$ Noor, "Nalar Keislaman Urang Banjar."
} 
secara dinamis seiring dengan kehadiran media baru internet yang tentunya akan memberikan nuansa lain dari keberagamaan Masyarakat Banjar.

\section{Simpulan}

Dari tulisan ini, ada beberapa kesimpulan yang dapat ditarik. Pertama, bahwa Islam Banjar masih sangat kental akan budaya lokal warisan leluhur, walaupun melalui proses akomodasi. Kedua, sosok ulama menjadi sentral kehidupan masyarakat Banjar, baik sebagai pemuka agama ataupun pemimpin kemasyarakatan. Ketiga, klasifikasi tipologi nalar keberagaman masyarakat Banjar pada akhirnya sangat dipengaruhi oleh dua hal di atas. Upaya pembaharuan yang bersifat kritis yang dilakukan oleh kalangan akademisi belum mampu merubah sifat tradisional wajah Islam Banjar. Keempat, klasifikasi di atas bukan menjelaskan pola keberagamaan masyarakat Banjar yang berevolusi linier, namun sifatnya lebih pada overlapping.

Pada akhirnya, tulisan ini adalah bentuk upaya penulis memetakan nalar keberagamaan yang berkembang dalam masyarakat Banjar. Harapan penulis tulisan ini mampu mampu memperkaya wawasan Islam yang berkembang di Nusantara, khususnya memperkenalkan nalar keberagamaan Islam yang berkembang di Kalimantan Selatan.

\section{Daftar Pustaka}

Al-Asfahani, Abu al-Qasim al-Husayn ibn Muhammad Raghib. Al-Mufradat fi Gharib al-Qur'an. Beirut: Turath For Solutions, 2013.

Al-Jabiri, M. Abid. Bunyah Al-Aql al-Arabiy. Beirut: Markaz Dirasat al-Wihdah al-Arabiyyah, 1990.

- Takwin Al-Aql al-Arabiy. Beirut: Markaz Dirasat al-Wihdah alArabiyyah, 1989.

Analiansyah. Aspirasi Pendidikan Masyarakat Banjar. Banjarmasin: Antasari Press, 2007.

Arkoun, Muhammad. Tarikhiyyah Al-Fikr al-Arabiy al-Islamiy. Libanon: Markaz al-Inma' al-Koumi, 1986.

Bahasa (Indonesia), Pusat. Kamus Besar Bahasa Indonesia. Jakarta: Gramedia Pustaka Utama, 2008.

Bardjie, Ahmad. Refleksi Banua Banjar: Kumpulan Tulisan Seputar Kesultanan Banjar, Sejarah, Agama, Dan Sosial Budaya. Martapura: Pustaka Agung Kesultanan Banjar, 2011. 
Basuni, Ahmad. Nur Islam Di Kalimantan Selatan: Sejarah Masuknya Islam Di Kalimantan. Bina Ilmu, 1986.

Berger, Peter L. Tafsir Sosial atas Kenyataan: Risalah tentang Sosiologi Pengetabuan. Jakarta: LP3ES, 1990.

Buseri, Kamrani. "Kesultanan Banjar Dan Kepentingan Dakwah Islam." AlBanjari: Jurnal Ilmiah Ilmu-Ilmu Keislaman 11, no. 2 (2012). https://doi.org/10.18592/al-banjari.v11i2.457.

Daradjat, Zakiah. Ilmu Jiwa Agama. Jakarta: PT. Bulan Bintang, 1996.

Daud, Alfani. Islam dan masyarakat Banjar. RajaGrafindo Persada, 1997.

F, Ahmad Gaus A. Sang Pelintas Batas: Biografi Djohan Effendi. Edited by Hairus Salim. Jakarta: Penerbit Buku Kompas, 2009.

Faridah, Siti. "Kebebasan Beragama Dan Ranah Toleransinya." Lex Scientia Law Review 2, no. 2 (2018): 199-214. https://doi.org/10.15294/lesrev.v2i2.27585.

Hadi, Sumasno. "Studi Etika Tentang Ajaran-Ajaran Moral Masyarakat Banjar." Tashwir, Jurnal Penelitian Agama Dan Sosial Budaya 3, no. 6 (2015). https://doi.org/10.18592/jt.v3i6.594.

Hakiki, Kiki Muhamad. "Politik Identitas Agama Lokal (Studi Kasus Aliran Kebatinan)." Analisis: Jurnal Studi Keislaman 11, no. 1 (2011): 159-74. https://doi.org/10.24042/ajsk.v11i1.617.

Hapip, Abdul Djebar. Kamus Banjar-Indonesia. Jakarta: Pusat Pembinaan dan Pengembangan Bahasa, Departemen Pendidikan dan Kebudayaan, 1977.

Harb, Ali. Kritik Nalar Al-Qur'an. Yogyakarta: LKiS, 2003.

Haris, Munawir. "Agama Dan Keberagamaan: Sebuah Klarifikasi Untuk Empati." Al'Adalab 16, no. 2 (2016). http://ejournal.iainjember.ac.id/index.php/aladalah/article/view/160.

Hasan, Ahmadi. Adat Badamai: Interaksi Hukum Islam dengan Hukum Adat pada Masyarakat Banjar. Banjarmasin: Antasari Press, 2007.

Ideham, M. Suriansyah, Syarifuddin, M. Zainal Arifin Anis, and Wajidi. Urang Banjar dan Kebudayaannya. Penerbit Ombak, 2015.

Ipansyah, Nor. Bagampiran dan Pemakaian Jimat dalam Masyarakat Banjar. Banjarmasin: Antasari Press, 2010.

Ismail, Roni. "Keberagamaan Koruptor Menurut Psikologi (Tinjauan Orientasi Keagamaan Dan Psikografi Agama)." ESENSLA: Jurnal Ilmu-Ilmu Ushuluddin 13, no. 2 (2012): 289-304. https://doi.org/10.14421/esensia.v13i2.743. 
Makmur, Ahdi. "Peranan Ulama Dalam Membina Masyarakat Banjar Di Kalimantan Selatan." MIQOT: Jurnal Ilmu-Ilmu Keislaman 36, no. 1 (2012). https://doi.org/10.30821/miqot.v36i1.114.

Mujiburrahman, Mujiburrahman. "Tasawuf di Masyarakat Banjar: Kesinambungan dan Perubahan Tradisi Keagamaan." Kanz Philosophia: A Journal for Islamic Philosophy and Mysticism 3, no. 2 (2013): 153-83. https://doi.org/10.20871/kpjipm.v3i2.46.

Murniati. "Pengembangan Keberagamaan Siswa dalam Aspek Akhlak melalui Metode Keteladanan di SD Alam Bandung." Atthulab: Islamic Religion Teaching and Learning Journal 4, no. 1 (2019): 49-58. https://doi.org/10.15575/ath.v4i1.2948.

Nadhiroh, Wardatun. "Kitab Sanjata Mu'min: Sebuah Bentuk Tafsir Awam Di Tanah Banjar." SUHUF Jurnal Pengkajian Al-Qur'an Dan Budaya 11, no. 1 (2018): 119-143.

. "Religious and Gender Issues in the Tradition of Basurung and the Polygamy of Banjar Tuan Guru in South Kalimantan." Al-Albab 6, no. 2 (2017): 263-80. https://doi.org/10.24260/alalbab.v6i2.674.

Noor, Muhammad Iqbal. "Nalar Keislaman Urang Banjar." Al-Banjari : Jurnal Ilmiah Ilmu-Ilmu Keislaman 10, no. 2 (2011). https://doi.org/10.18592/al-banjari.v10i2.935.

Pals, Daniel L. Seven Theories of Religion. Oxford University Press, 1996.

Permata, Ahmad Norma. Metodologi Studi Agama. Yogyakarta: Pustaka Pelajar, 2000.

Ras, J. J. Hikayat Banjar. Kuala Lumpur: Dewan Bahasa dan Pustaka Kementerian Pendidikan Malaysia, 1990.

Sarmadi, A. Sukris. "Transformasi NU Dalam Masyarakat Banjar Kini Perspektif Pergeseran Gerakan Keagamaan Di Kalimantan Selatan." Dialog 32, no. 2 (2009): 25-40.

Sarmadi, Ahmad Sukris. "NU Dalam Bingkai Masyarakat Banjar: Arah Pergerakan Islam Kultural Dan Islam Non Kultural Di Kalimantan Selatan." Jurnal Theologia 21, no. 1 (2010).

Semi, M. Atar. Anatomi sastra. Bandung: Angkasa Raya, 1993.

Supriansyah, Supriansyah. "Agresi Kultur Digital dan Konsumerisme ada Identitas Urang Banjar di Era Pascamodern." Al-Banjari: Jurnal Ilmiah Ilmu-Ilmu Keislaman 18, no. 1 (2019): 103-26. https://doi.org/10.18592/al-banjari.v18i1.2544. 
Syafruddin, and Syahriansyah. Ajaran Tasawnf Syekh Hamid Abulung. Yogyakarta: Sumbangsih Press, 2007.

Syaharuddin. Orang Banjar Menjadi Indonesia: Dinamika Organisasi Islam di Borneo Selatan, 1912-1942. Yogyakarta: Eja Publisher, 2009.

Syukur, Amin. Pemikiran-pemikiran Syekh Mubamad Arsyad al-Banjari dalam Bidang Taubid dan Tasawuf. Center for Community Development Studies Kalimantan, 2009.

Thahir, A. Halil. "Dari Nalar Literalis-Normatif Menuju Nalar KontekstualisHistoris Dalam Studi Islam." ISLAMICA: Jurnal Studi Keislaman 5, no. 1 (2010): 1-14. https://doi.org/10.15642/islamica.2010.5.1.1-14. 